\title{
Righteousness and identity formation in the Sermon on the Mount
}

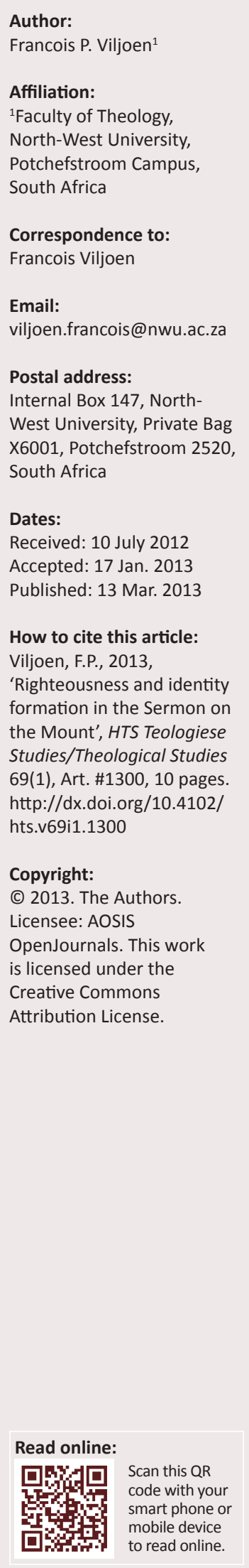

Righteousness is an important term in the first gospel and has a significant concentration in the Sermon on the Mount. The argument in this article is that the first gospel has a community building function. Matthew intentionally uses the word 'righteousness' in the Sermon on the Mount as an instrument to define the identity of his community. Though righteousness can be used in a soteriological sense, it is argued that Matthew mainly uses it in an ethical sense. By righteousness Matthew refers to the proper behavioural norms and attitudes for his community. Commitment to Jesus forms the central focus of the community's identity. Their discipleship is demonstrated by doing the will of God as defined and interpreted by Jesus. Doing the will of God in such a manner is what Matthew regards as the distinguishing mark of this community. Thus they would surpass the righteousness of the scribes and Pharisees.

\section{Introduction}

The intention of this article is to demonstrate how Matthew uses 'righteousness' as identity marker. Righteousness is a fundamental term in the Matthean gospel and has a significant concentration in the Sermon on the Mount (Thom 2009:314). It plays a considerable role in how Matthew describes the function of the Law and the position of his community (Deines 2004:124). With this word, he is probably trying to correct and reinforce some issues in the social setting of the community (Carter 2000:13-14; Przybylski 1980:105-116; Tagawa 1970:149).

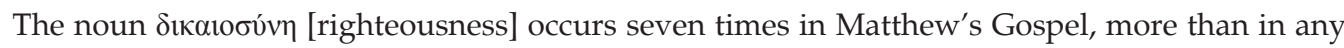
other writing of the New Testament, except for Romans and 2 Corinthians (cf. Talbert 1992:777 for the distribution of the word in the New Testament). This term only occurs in sayings by Jesus. These sayings are either unique to Matthew (Mt 3:15; 5:10, 20, 6:1; 21:32) or are shared by Luke

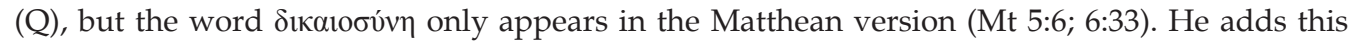
word in cases where synoptic parallels do exist, and he repetitively uses it in the Sermon on the Mount. The argument in this article is that Matthew intentionally utilises the term of righteousness to define the identity of his community in contrast to outsider groups. Righteousness is used to describe the proper behavioural norms of his community which distinguish them from outsiders. The Gospel not only reflects their norms but also impacts on their identity as followers of Jesus.

Matthew uses righteousness to refer to Jesus, John the Baptist and the disciples. ${ }^{1}$ In two cases, he contrasts the righteousness of the disciple with that of the Pharisees and teachers of the Law. This suggests that Matthew probably uses the word as identity marker for his community. All seven cases reveal remarkable significance and meaning related to Matthew's teaching of the Law: ${ }^{2}$

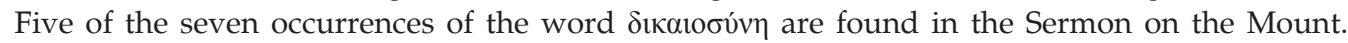
This concentration indicates that the term represents an important theme in the Sermon on the

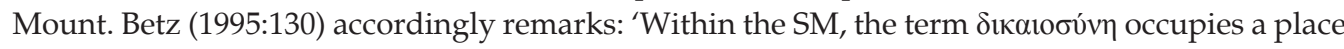
of central importance' and Davies and Allison (2004:499) write: 'The word "righteousness" ... expresses the essence of the sermon on the mount.'

\section{Identity formation in the gospels}

Kilpatrick (1946:59-100) convincingly draws attention to the fact that the gospel seeks to shape a community of disciples. It has a formational function in addition to its informational function (Carter 2000:8). The study of Burridge (1992) on the genre of the gospels illustrates this point.

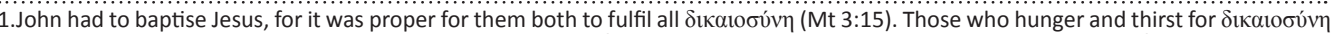

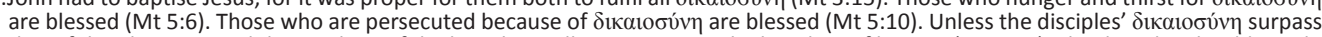
that of the Pharisees and the teachers of the law, they will not enter into the kingdom of heaven (Mt $5: 20$ ). The disciples should not do

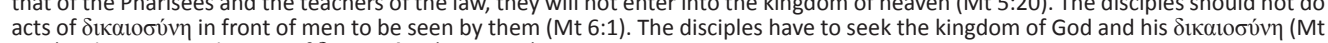

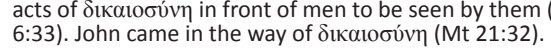

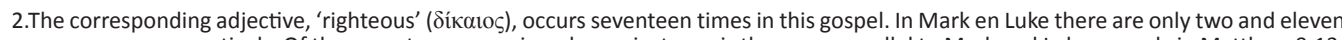
occurrences respectively. Of the seventeen cases, in only one instance is the usage parallel to Mark and Luke, namely in Matthew 9:13: 'For I have not come to call the righteous, but sinners' (parallel to Mk 2:17 and Lk 5:32). Six other cases occur in pericopes or passages with synoptic parallels but where 'righteous' is not used in the parallel passages. These additions in Matthew's versions signify some redactional trend in Matthew's use of the adjective too. 
He persuasively argues that the gospels belong to the genre of ancient Greco-Roman biographies ( $\beta 101)$. Such biographies originated amongst groups of people who were formed around charismatic leaders and teachers (Burridge 1992:80). Typical of this genre, the gospels focus their attention on Jesus of Nazareth. Like the ancient bioi, the gospels do not only instruct and express the adoration of Jesus but also set a model for the audience to follow (Burridge 1992:214). Thus the gospels have a community-building function. They present Jesus as the expression and norms of their communities' values (Talbert 1992:749). Accordingly, the gospels are identity-forming and lifestyle-shaping narratives (Carter 2000:8). 'Identity' here refers to that which defines the central commitment of the members of the community. It shapes the appropriate way of life, set of practices and behaviours.

This argument can also be demonstrated by the social sciences, as they express the relation between identity formation and behavioural norms. Theissen (2007:15-17) explains how psychology and the social sciences can be used as 'hermeneutical' or 'heuristic' tools to understand historical texts. He explores internal mental processes to discover how people perceive, remember, think, speak and solve problems (cf. Neisser 1967) in order to understand the texts from the past. $^{3}$

Scholars have identified a variety of devices that groups in the Greco-Roman world employed to define themselves and outsiders (Sanders et al. 1982; Neusner \& Frerich 1985; Saldarini 1994). Many of these devices can be recognised in Matthew too, as Carter (2000:9-11) has argued:

- Naming: Names such as disciples, blessed and church are used to reinforce group identity and to warn them not to be like the other groups.

- Central focus: Commitment to Jesus forms the central focus of the community's identity (e.g. Mt 4:19-22; 9:9; $10: 1-4 ; 19: 21)$

- Claims of exclusive revelation: The gospel presents Jesus as the revealer of God's presence (Mt 1:23; 28:20), will (Mt $5-7 ; 10,13,18,24-25)$, reign (Mt 4:17) and forgiveness (Mt $1: 21 ; 9: 1-8 ; 26: 28)$.

- Rituals and association: Worship (Mt 2:1-12; 5:23-24), teaching (Mt 7:24-27), baptism (Mt 28:19), appropriate interaction with other members (Mt 6:14-15; 22:38-39; 18:15-20), et cetera are features that strengthen the identity of the community.

- Social organisation: The community makes decisions about appropriate behaviour and has its own disciplinary structures (Mt 18:15-18).

- Critical of opponents: Matthew vilifies Jesus' opponents by naming them the enemy, hypocrites, blind guides, evil, serpents, brood of vipers, et cetera.

- Apocalyptic eschatology: The righteous and the wicked have two distinct destinies. God will punish the wicked and vindicate the oppressed righteous (Mt 13:24-25; 25:31-46).

3. Roitto (2011) relates to Theissen by demonstrating how cognitive sciences provide framework to understand the relationship between identity and behavioural norms in the letter to the Ephesians.
- Community definition by origin: The Gospel begins with Jesus' genealogy, miraculous conception and early childhood (Mt 1-2). Jesus brings the community into existence (Mt 1:21; 4:18-22; 9:9; 10:1-4).

- Community definition by actions: The five teaching sections (Mt 5-7; 10; 13; 18; 24-25) outline the appropriate actions for the community.

When considering Matthew's use of the word 'righteousness', it appears to describe one of the primary actions or virtues expected from the community.

The intention of this article is to demonstrate how Matthew uses 'righteousness' as identity marker. He was writing to his community, who were mainly Jewish and estranged from the synagogue, its people and community (Carter 2000:30; Saldarini 1994:54; Tagawa 1979:149). In his gospel, Matthew counters Jewish suspicion against his community for following Jesus and for accepting his teaching as normative for their religious behaviour (France 1989:99). The evangelist seeks to assure his community that they are not abrogating the Torah, but by following the commands of Jesus, they are actually fulfilling it by bringing it to a higher standard of righteousness (Viljoen 2011:403-404).

\section{Righteousness in the Sermon on the Mount}

The Sermon on the Mount forms one of the five teaching blocks in the Gospel (Mt 5-7; 10, 13, 18; 24-25), each closed by a similar refrain 'and when Jesus had finished' (Talbert 2010:6). In these teachings, Matthew's Jesus instructs his disciples about attitudes and practices that distinguish them from other people and exhorts them to persevere faithfully (Carter 2000:8).

TheSermon on the Mount is also referred to as the Constitution of the Kingdom of heaven (Van der Walt 2006:185). Those who encounter the empire of heaven must live in an appropriate manner. In their daily lives and interaction with other people, the citizens of the Kingdom are called upon to live according the will of God: 'Die Bergpredigt enthält also eine missionarische Jünger-Ethik' [The Sermon on the Mount therefore contains a missionary discipleship ethics] (Deines 2004:446). This in itself signifies that righteousness in the Sermon probably refers to the fulfilment of the Torah by enacting the will of God. The Sinai typology might already be implied at the beginning of the Sermon where Jesus went up the mountain to teach (Mt 5:1-2; ${ }^{4}$ Floor 1969:34; Loader 1997:165). This opening leads to an anticipation of a new revelation to be delivered by a new Lawgiver. The expectation is met where Jesus states that $\mathrm{He}$ did not come to abolish the Law but to bring it to fulfilment (Mt 5:17-19) and that He repeatedly refers to the meaning and intention of the Law in the halakhic argument of Matthew 5:21-48. He calls his followers to do the will of God in a way that supersedes that of the scribes and Pharisees ${ }^{5}$ (Mt 5:20, 4.The phrase 'went up the mountain' was frequently used to describe Moses going up Sinai to receive the Decalogue (Ex 19:3; 24:12, 13, 28; 34:2, 4; Dt 9:9; 10:1, 3).

5.The scribes and the Pharisees are the stereotypical opponents in the first Gospel. 
48; 6:1-18). Besides the Sinai typology, an allusion to Mount Zion $^{6}$ might also have been implied (Carter 2000:130). At Mount Zion, nations would come to learn of God's ways.

When Jesus sat down to teach, his disciples came to him. This is the first instance where the term 'disciple' is used to identify the followers of Jesus. In the Greco-Roman and Jewish worlds, this word was used for adherents of a recognised master (Wilkins 1988).

The Sermon on the Mount sketches a society of justice in contrast to the values, commitments and practices of the majority who do not form part of the kingdom of heaven (Carter 2000:128; Thom 2009:338). The sermon shapes and strengthens the community's identity and lifestyle, which differs from the dominant society. The community is reminded of the importance of their interaction with God, one another and the surrounding society.

Righteousness forms a key theme in the Sermon on the Mount, extending from Matthew 5:6 where it first appears in the Beatitudes through to the conclusion of his argument in Matthew 6:33. The concept of righteousness in Matthew 5:20 and 6:1 furthermore forms an inclusio around the halakhic antitheses of Matthew 5:21-47. By way of the antitheses, Matthew illustrates the new righteousness that is called for. After these positive statements about appropriate conduct, Matthew 6:1 forms a hinge to introduce critique of inappropriate behaviour (Mt 6:1-18).

Kennedy (1980:39-63) and Mack (1990:82-85) suggest that the Sermon on the Mount be analysed in terms of the parts of classical rhetorical speech. By referring to these suggestions and with some variations to details, Thom (2009:315-316) proposes the following outline of the composition:

1. Exordium (Introduction): Defining the righteous disciple (Mt 5:3-16).

Beatitudes (Mt 5:3-12).

Metaphors of salt and light (Mt 5:13-16).

2. Propositio (Statement of the theme): Exceeding righteousness (Mt 5:17-20).

True fulfilment of the law (Mt 5:17-18).

Exceeding righteousness (Mt 5:19-20).

3. Probatio (Argument): Understanding and practicing the righteous life (Mt 5:21-7:21).

Righteousness and the interpretation of the law (Mt $5: 21-48)$.

Righteousness and piety (Mt 6:1-18).

Righteousness and priorities (Mt 6:19-34).

Judgement and discrimination, actions and consequences (Mt 7:1-11).

4. Peroratio (Conclusion): Warnings regarding words and actions of the religious life (Mt 7:13-27).

From this proposed view of the composition of the Sermon on

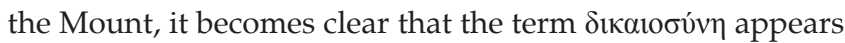
at important positions in the Sermon. It is found at the beginning of the exordium (Mt 5:6;10) and at important central and closing positions in the Beatitudes. In the propositio, the term is used to broaden the theme by demanding of the

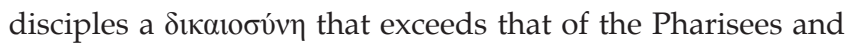

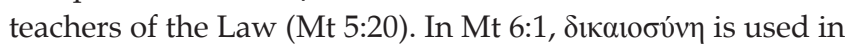
the introduction to the second part of the probatio to warn that righteousness should not be practiced to be applauded by

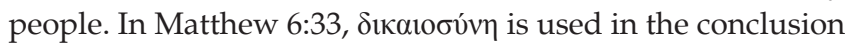
of the third part of the probatio to urge the disciples to seek righteousness as their first priority.

\section{Righteousness in the exordium to the Sermon on the Mount}

The beatitudes (Mt 5:3-12) form the exordium to the Sermon on the Mount. Various scholars have indicated that the beatitudes were common pronouncements in the Greek language and formed a specific genre (cf. Van Aarde 1994:163). Some formgeschichtlichen and gattungsgeschichtlichen studies have been done on the beatitudes as such. Koch (1974:21-23) is a prominent exponent arguing for a gattungsgeschichtlice past behind the series of beatitudes (see Viljoen 2012:1 of 1). The beatitudes refer to a religious prophecy of salvation regarding joy or blessing of some nature that implies eschatological participation. It conveys the meaning that it will ultimately be well with those who first seek God's kingdom (e.g. Mt 6:33).This style of blessing can be called 'an indirect exhortation', which induces a particular pattern of ethical behaviour (Domeris 1990:68). God will comfort these people at the final restoration (Keener 1999:166). The beatitudes do not only concern emotions, or personal qualities, but God's favour for certain attitudes and actions (Carter 2000:130)

As declarative statements, the beatitudes in Matthew pose theological dogma ${ }^{7}$ with regard to the eschatological distinctive religious joy of the righteous, who share in the salvation of the Kingdom of God (Lioy 2004:120). The beatitudes also imply the judgement of God as supreme Judge, anticipating his eschatological verdicts. The ultimate mercy of God will be revealed on the day of the judgement (Keener 1999:166). Principles of eschatological divine justice are pronounced, and these impact on the present: 'Divine justice not only is above time and space but also reaches into time and space' (Betz 1995:96). These principles lay claim on the recipient to respond with an appropriate conduct of life. By revealing this new way of life, the beatitudes effect moral behaviour. The addressees have to respond with adequate attitudes, actions and thoughts that are different to conventional ways of behaviour (Luz 1990:221). Therefore the set of beatitudes describes the way of life of faithful disciples of Jesus. Ethical exhortations are embedded in promises and encouragements of gracious blessings. Matthew's Jesus used a standard literary form of the Hebrew Bible as found in Psalm 1:1-2: 'Blessed is the man who does not walk in the counsel of the wicked ... But his delight is in the law of the Jewish wisdom literature, wisdom is based on the divine justice as revealed in the Torah (Betz 1995:94) 
the Lord' (Keener 1999:165). For Matthew, the beatitudes describe the life of Jesus' disciples and the parameters of conduct for his community: 'The Beatitudes sketch the attitudes that the Matthean Christians should manifest and allude to the suffering that they endured' (Betz 1995:92-95; Harrington 1991:82).

Hanson (1994:100-101) indicates the relationship between the beatitudes and the values of honour and shame. They present behaviour and attitudes that God considers as honourable and which the community should also value (Carter 2000:576). Whilst they are declarations of favour, they also encourage what is regarded as favoured behaviour.

It appears that Matthew employs these beatitudes to reinforce the identity of his group. They define features of a faithful, favoured, blessed and honourable group (Carter 2000:130). By calling them the blessed ones, he separates them from other groups. Their commitment to Jesus must be strong enough to withstand persecution for his sake (Mt 5:11-12). Though oppressed in the present, they will be rewarded in heaven (Mt 5:12). In this way, the beatitudes constitute and affirm the community's unique identity and practices.

The beatitudes reveal numerical arrangements of sayings which are common in gnomonological literature. Green (2001:176ff.) examined the relationship between the beatitudes and discovered a complex web or relationships between the individual beatitudes. ${ }^{8}$ The first beatitude of the Sermon on the Mount (as in the Sermon on the Plain) heads the list forming the basis. Those that follow are climactic developments to reach the ultimate climax in Matthew 5:12. In addition to this, the same phrase in $3 b$ and $10 b$ (ő $\tau 1 \alpha v i \tau \tilde{v} v$

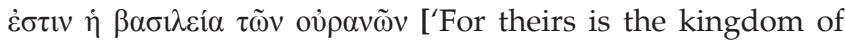
heaven']) forms an inclusio around $5: 4-9^{9}$ by which the

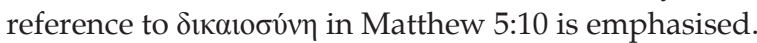

The sequence of eight beatitudes is divided into two sections

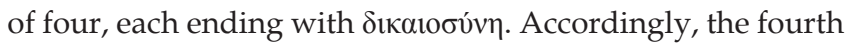
and eighth beatitudes form a parallel construction. These two beatitudes are the longest of the series of eight in Matthew $5: 3-10$, indicating the relative importance of these two beatitudes ${ }^{10}$. The first group of beatitudes probably alludes to Isaiah 61 where oppressive situations are described, but these will be reversed because the oppressed are honoured by God. The next four beatitudes describe human actions honoured by God as they express God's transforming reign until its completion (Carter 2000:131; Deines 2004:138). After the set of eight descriptive beatitudes in which the audience is addressed indirectly, the ninth beatitude follows as conclusion, addressing the recipients directly. In this direct

8.The poor in spirit and the meek are variations on the theme of the 'anawim'. Less directly, also those persecuted for righteousness form part of this group. The merciful converse with the poor in spirit and the peacemakers with the meek. The mourners humbling themselves before God express their humility in awareness of mourners humbling themselves before God express their humility in awareness of pure in heart forms the climax of the composition.

9.Within the context of the Sermon on the Mount, Jesus is clearly portrayed as the King of this Kingdom.

10.The relative importance of a statement is often emphasised by an increase in length (Thom 2009:325) address, the audience is encouraged to persist in its loyalty to Jesus even when they are persecuted for his sake.

With these preliminary observations in mind, one can now

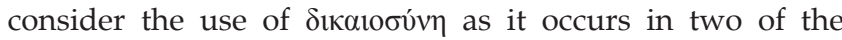
beatitudes.

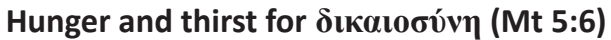

Matthew's Jesus speaks metaphorically of an intense longing for righteousness in terms of hunger and thirst: $\mu \alpha \kappa \alpha$ pror oi

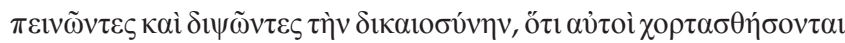
['Blessed are those who hunger and thirst for righteousness, for they will be filled'].

This beatitude is the equivalent of Luke 6:21a: 'Blessed are those who hunger now, for you shall be satisfied'. From this comparison, it appears that Matthew redactionally added 'and thirst after righteousness' (Davis \& Allison 2004:451). The Greek grammar in this addition is somewhat awkward with the accusative after 'hunger and thirst' and the lopsided correspondence of $\chi 0 \rho \tau \alpha \sigma \theta \eta \dot{\sigma o v} \sigma \alpha$ with $\pi \varepsilon 1 v \tilde{\omega} v \tau \varepsilon \varsigma$ and not

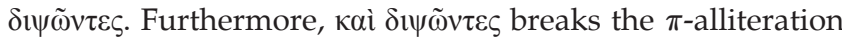
in the first four beatitudes: $\pi \tau \omega \chi 0 \grave{,}, \pi \varepsilon v \theta 0 \tilde{v} \tau \varepsilon \varepsilon, \pi \rho \alpha \varepsilon \bar{\iota} \zeta$ and $\pi \varepsilon เ v \tilde{\nu} \nu \tau \varepsilon \varsigma$.

Two opposite interpretations of righteousness can be considered. The first option would be to interpret it as God's eschatological gift of justice that would come in the eschatological era (Deines 2004:148-154). Bratcher (1989:234) suggests a corresponding paraphrase of the text: '... whose greatest desire is that God's purpose prevails.' As the beatitudes are intended to encourage the downtrodden, an eschatological interpretation would fit the context well (Hagner 1992:112). Righteousness could refer to God's exercise of justice, leading to the eschatological vindication of the poor, meek and persecuted disciples (Bultmann 1951:273; Deines 2004:154; Gundry 1982:70). With such an interpretation, righteousness would involve the realisation of Old Testament prophecies such as those found in Isaiah 61:211 and Psalm 37:11.12 Furthermore, such an interpretation is closer to the corresponding beatitude in Luke 6:21: 'Blessed are you who hunger now, for you will be satisfied.' Matthew would then have expanded it to include righteousness in the sense of eschatological justice. With the probable allusion to Isaiah 61 in mind, righteousness would refer to God's righteous punishment of a society that deprives the downtrodden of life and resources for living (Carter

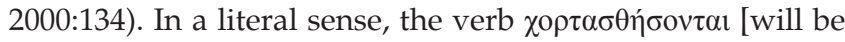
filled] in the motivating clause obviously fits this meaning of righteousness better than the sense of ethical righteousness, though in Jewish literature the combination between 'hunger' and 'thirst' is quite often used in a metaphorical sense (cf. Ps 42:2).

The opposite interpretation would be to interpret righteousness here in an ethical sense as a virtue required

11.Isaiah $61: 2$ : '... to proclaim the year of the Lord's favour and the day of vengeance of our God.'

12.Psalm 37:1: 'But the meek will inherit the land and enjoy great peace.' 
from the disciples. In such a case, this beatitude refers to righteousness as desire and aim to live in full accordance to the will of God (Davies \& Allison 2004:452; Strecker 1971:156; Turner 2008:151). This meaning relates to the Jewish sense of the word that implies the ideal conduct in adherence to God's ordinances (Przybylski 1980:17-19) ${ }^{13}$. One cannot have this strong desire to live according God's will without, at the same time, strongly desiring to do what is right (Morris 1992:99). Plummer (1915) explains these metaphors strikingly:

To believe oneself to be in possession of righteousness, like the Pharisee in the parable is fatal ... One must feel the want of it, and have a passionate and persistent longing for it. (p. 65)

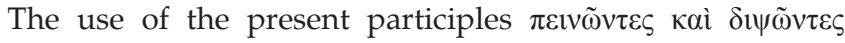
[hunger and thirst] should be noted. It implies that righteousness is something that should continuously be desired: 'Righteousness should ever be sought, must always be a goal which lies ahead: it is never in the grasp' (Davies \& Allison 2004:453). Such ethical conduct designates the highest form of true discipleship. This beatitude functions as an encouragement to the community to strive towards living according to the standards that Jesus has set. God's will should be done on earth as it is done in heaven (Mt 6:10).

The second interpretation fits well into Matthew's nuance and broader context. Matthew frequently emphasises the correct lifestyle for the followers of Jesus in contrast to that of the scribes and the Pharisees. Stott (1978:10) speaks of a 'counter culture' of the followers of Jesus. Matthew criticises hypocrites for boasting about their righteous accomplishments (cf. Mt 6:1-2). His community should rather realise their lack in attaining the right behaviour before God, and then they will receive what they are longing for as a gift: 'A humble person who acknowledges sin not a smug one who congratulates himself on is goodness - receives God's endorsement' (Turner 2008:152). The first three beatitudes would then express the need to admit one's spiritual poverty, to mourn over sin and oppression and to rest in God's care amidst oppression (Mt 6:3-5). The fourth beatitude would fit this set by expressing the need to hunger for living according to God's will. One should furthermore ask why Matthew, in comparison to Luke 6:21, has expanded the Vorlage to add the term righteousness. It could be that Matthew thus made this beatitude part of the main argument in the Sermon on the Mount about the righteous living of the followers of Jesus. This confirms the argument that Matthew used righteousness as a significant concept.

The objection that such an ethical interpretation of righteousness would contradict Matthew's teaching on salvation need not be compelling. Ethical conduct, living in keeping with the will of the Father, does not exclude grace (Morris 1992:99). Matthew's argument is not that righteous behaviour earns salvation, but that it is the fruit of insights into God's ways ${ }^{14}$ (Guelich 1982:371; Luz 1990:221). Righteousness

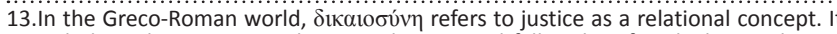
includes other virtues such as goodness, good fellowship, fair dealing and piety (Thom 2009:324). This meaning also fits the context of this beatitude well.

14.These attitudes are comparable with what Paul labels the 'fruit of the Spirit' (G 5:22) but should be distinguished from the 'works of the law'. Stott (1978:31) remarks: 'Just as the nine fold fruit of the Spirit which Paul lists is to ripen in every Christian character, so the eight beatitudes which Christ speaks describe his ideal for every citizen of God's Kingdom.' These attitudes, actions and thoughts are different from what the Greeks call 'virtues', being approximations towards the divine absolute. does not create a relationship with Jesus but is the result thereof. It is a given righteousness, not an achieved one. The blessed one does not achieve it but hungers and thirsts for it. 'They will be filled' surely means that God will fill them. The fact that humans cannot produce such righteousness demonstrates how rich this concept is. Humans cannot rely on their own power to achieve righteousness, but they can rely on God.

Between these two most extreme interpretations of righteousness on a continuum of possible interpretations, the Hebrew and Greco-Roman notions of righteousness should be considered (Betz 1995:130).${ }^{15}$ Righteousness is a social value which refers to commitments and relationships. Accordingly, God's and human righteousness are not independent of each other. God is righteous in that He acts faithful to his covenantal commitments to deliver his needy and oppressed people from an unjust society. For their part, his people are committed to act faithful to covenantal requirements (Guelich 1982:372). With such a reading, the fourth beatitude provides a vision of a society where God's empire is already at work. This vision shapes a community who lives in this 'now and not yet' state. They expect God's final vindication, whilst living a righteous life under God's current transforming reign.

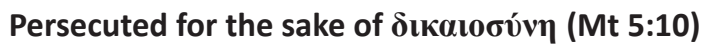

With the eighth beatitude Matthew's Jesus warns his disciples that their behaviour will be received by resistance: $\mu \alpha \kappa \alpha$ pıเ

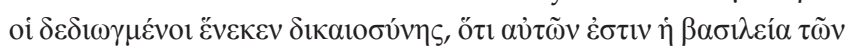

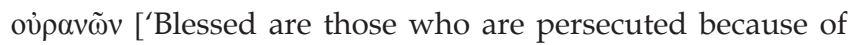
righteousness, for theirs is the kingdom of heaven'].

There is no counterpart to this beatitude in Luke. ${ }^{16}$ Matthew thus once again emphasises the important motif of righteousness in his argument.

According to this beatitude, righteousness is the cause of persecution (Davies \& Allison 2004:459). Matthew's audience probably had some experience of persecution and would not be surprised at this beatitude. Matthew uses the verb persecute $(\delta i \omega \kappa \omega)$ four times in this chapter (Mt 5:10, 11, 12, 44) and twice elsewhere (Mt 10:23; 23:34) all referring to the persecution of Jesus' followers. In the New Testament as a whole, this verb is also mostly used for the infliction of suffering on people who believe and act in a manner that the establishment finds strange (Morris 1992:101). The just way of living (Mt 5:3-9) challenges society outside, its power structures and its beneficiaries. Society certainly would strike back (Carter 2000:136). Matthew's Jesus speaks of those who are committed to conduct that is appropriate for people under

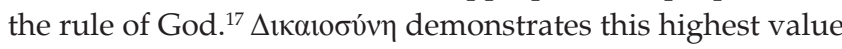

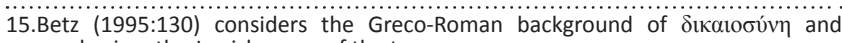
emphasises the Jewish sense of the term.

16.Beare (1981:133) and Guelich (1982:93) suggest that this evidences a redactiona genesis.

17.The rule of God most probably has some intertextuality with the most visible kingdom of its time, namely Rome's empire and its righteousness. Followers of Jesus recognise God's empire instead. 
of discipleship that marks the life of those who live under God's rule as King. Disciples respond to persecution not by giving up, nor by retaliation. Clearly there is no reason why righteousness in this beatitude should not be understood in an ethical sense. Whilst salvation is grace, there is a kind of conduct expected from those who received God's gift. Based on their relationship with Jesus, they enact the righteousness of God's saving reign.

Just as the first four beatitudes form a set that is concluded with the first statement on righteousness, the fifth to the eighth beatitudes also form a set. The beatitudes in the second set all refer to right attitudes and good deeds, challenging the norms of an unjust society by showing mercy, being pure of heart and making peace (Mt 5:7-9). This series is concluded with the second reference to righteousness in the eighth beatitude.

Matthew 5:10 is very similar to a phrase found in 1 Peter 3:14: 'But even if you should suffer for what is right, you are blessed.' This is probably a reflection of the same logion contained in oral tradition (Hagner 1992:114). In 1 Peter, an ethical context is supposed as a question is posed in the previous verse: 'Who is going to harm you if you are eager to do good?' (1 Pt 3:13). This strengthens the possibility of an ethical use of the logion in Matthew 5:10. With this beatitude, Matthew explains to his community why they suffer persecution. He affirms that their beliefs are correct and encourages them to remain loyal to Jesus.

This beatitude is immediately expanded in Matthew 5:11-12

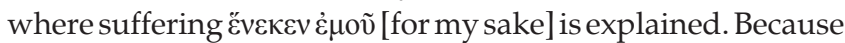
of their commitment to Jesus, his disciples could expect persecution for their righteous behaviour. This commitment demands more that those of Jesus' contemporaries. Although Jewish teachers would expect students to suffer for God's sake, they would not have called students to suffer for their own sake (Keener 2009:171).

The eighth beatitude therefore strongly reinforces commitment to Jesus as the central feature of the community's identity. He is more than an ordinary Jewish teacher. His disciples should act on his behalf amongst oppressive powers. It is also invective to the opponents who fail to recognise and accept God's agents.

\section{Righteousness as propositio to the Sermon on the Mount}

The propositio to the Sermon of the Mount is given in Matthew 5:17-20. In these verses, the theme of the Sermon in general is stated. The propositio is concluded with the

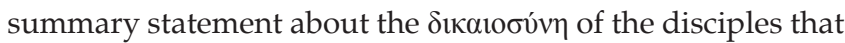
should surpass that of the scribes and the Pharisees (Mt 5:20) This verse also functions as immediate introduction to the antitheses in Matthew 5:21-48 with Jesus' interpretations on what righteousness means in practice. In such case, Matthew 5:20 is paralleled by Matthew 6:1, which is also followed by a series of practical examples.

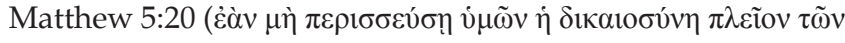

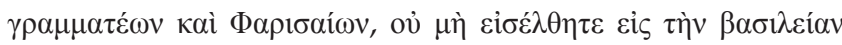

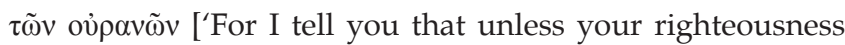
surpasses that of the Pharisees and the teachers of the law, you will certainly not enter the kingdom of heaven']) functions like a hinge between the preceding statement on the continuing validity of the Law (Mt 5:17-19) and the antitheses with their halakhic arguments that follow in the first part of the probatio (Mt 5:21-47; Davies \& Allison 2004:498).

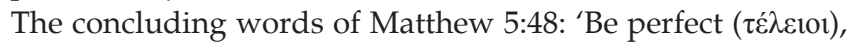

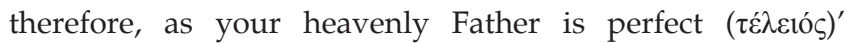
appears to be a restatement of the message in Matthew 5:20. Matthew 5:48 forms the culmination to the argument started in Matthew 5:20. Being 'righteous' is paralleled with 'being perfect'. By greater righteousness, Matthew points towards perfection.

Righteousness and perfection are described in the six halakhic examples of this exceeding righteousness in Matthew 5:21-47, between the introductory and concluding statements. The argument on the validity of the Law emphasises conduct that corresponds to God's will whilst the antithetical examples are 'instructions about the practice of eschatological righteousness' (Barth 1963:139). This righteousness refers to the life of justice that God's empire requires (Carter 2000:143; Deines 2008:81). Each of the antitheses is obviously intended to illustrate what exceeding righteousness means in practice. Within a polemical context, the antitheses offer exemplary illustrations of the requirements of true righteousness according to the model of God's own perfection. The introductory statement in Matthew 5:20 creates an expectation that the following series of sayings would provide an explanation and exegetical guide to what such righteousness implies. Obviously this righteousness refers to the practical side of one's religion. All six antitheses appear to deal with examples of conflict and broken relationships and instructions on how such relationships should be restored (Betz 1995:201-205; Thom 2009:328).

There can be very little doubt that the righteousness in Matthew 5:20 refers to ethical conduct, and for the following

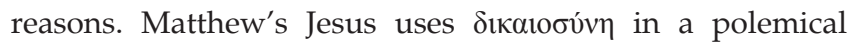
context because the righteousness that Jesus required far transcends what the scribes and Pharisees considered as righteous. This distinction of righteousness is qualitative

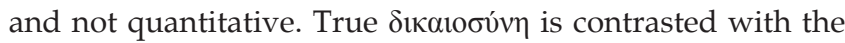
elaborate but superficial type of righteousness of the scribes and the Pharisees, which is criticised in Matthew 6:1. Betz (1995:193) suggests that this criticism includes hypocrisy (Mt 6:1-18) as the attitude of mere formal compliance with the written Law as well as the interpretation of the Law through tradition (Mt 5:20-48). According to Matthew, discipleship draws a distinction between true righteousness and merely strict legal correctness, for Christology is the foundation of ethics (Turner 2008:164). Stott (1978) remarks on Matthew's argument by saying:

Pharisees were content with an external and formal obedience, a rigid conformity to the letter of the law; Jesus teaches us that God's demands are far more radical than this. (p. 75) 
The author makes the identity of his community distinct with a strong dichotomy by comparing their righteousness with that of the scribes and the Pharisees. He shapes the identity and lifestyle of his community within a dominant culture that do not share their convictions.

Matthew assures his addressees that righteousness is the outcome of living according to the meaning and intention of the Law, as interpreted in the Sermon on the Mount. He advocates a righteousness that is based on his group's values, which surpass those of their opponents (Mt 5:20). The similarity with the hortatory epilogue of the halakhic letter from Qumran (4 QMMT) is striking. ${ }^{18}$ In a form of antithetical debate, the Qumran apologist assures his community that walking according to the interpretation presented in his legal antitheses will be reckoned as righteousness (Foster 2004:83). In Matthew, the disciples are instructed to observe everything Jesus has commanded them.

\section{Righteousness and piety in the probatio of the Sermon on the Mount}

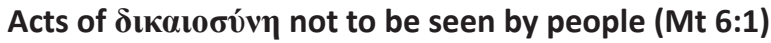

In Matthew 5:17-48, Matthew makes it very clear that Jesus is committed to and expecting the keeping of the true intention of the Law. Righteousness in God's kingdom (Mt 5:20) requires more than the formal obedience to the letter of the Law. Matthew's Jesus in Matthew 6:1 continues to describe another aspect by warning against hypocritical righteousness in Matthew 6:1-18.

Righteousness is once again used in a polemical context,

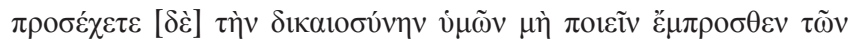

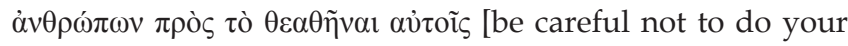
righteousness before men, to be seen by them]. The expression

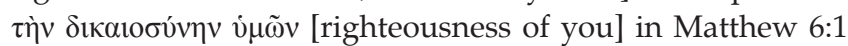

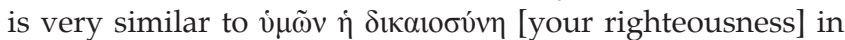
Matthew 5:20. The righteousness of Matthew 6:1 evidently refers back to the righteousness of Matthew 5:20 (Deines 2004:437). Whilst Matthew 5:20 deals with the nature of true righteousness in general, $\mathrm{Mt}$ 6:1 warns against the pitfalls of practising insincere righteousness (Strack \& Billerbeck 1961:386). Jesus contrasts the outward religious performances of the hypocrites to impress people with that of the disciples who aim to please their Father in heaven. Members of the Matthean community are encouraged to perform their acts of piety without pretence and in private where only God can see, not like the hypocrites who parade their pious acts in public to gain praise (Betz 1995:351; Davies \& Allison 2004:579; Sim 1999:122). In an honour and shame society, one's good reputation is sustained by the esteem of others who benefit from one's public actions (Carter 2000:158). Jesus therefore opposes a fundamental societal pattern.

There is very little reason to doubt that the ethical conduct of the disciples is intended in this verse (contra Deines 2004:421).

18.4QMMT (Miqsat Ma'ase ha-Torah or 'Some Precepts of the Law') was discovered at Qumran. Qimron and Strugnell (1994:25) dated this halakhic letter between the early 1st century BCE and the early 1st century CE. 4QMMT directly and indirectly early 1st century BCE and the early 1st century CE. 4QMMT directly and indirectly
makes use of the antithetical form of contrasting two opposing viewpoints in its makes use of the antithetical form of contrasting two opposing
halakhot to promote the viewpoint of the Qumran community.
Three specific activities follow, by which such righteousness is described:

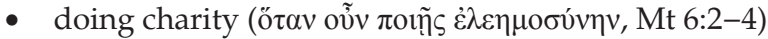

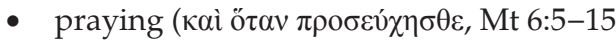

- fasting (ő $\alpha \nu \delta \delta \dot{\varepsilon} v \eta \sigma \tau \varepsilon v ́ \eta \tau \varepsilon$, Mt 6:16-18).

These three examples were central to Jewish piety during the Second Temple period ${ }^{19}$ (Betz 1995:338; Morris 1992:135). Tobit $^{20}$ 12:8-9 links these three deeds to one another and prioritises giving alms. ${ }^{21}$ The problem with the hypocrites in Matthew was not that they did not perform these acts but that they performed them insincerely. The hypocrites made people into spectators by impressing them in order to sustain their own status. The first example of true or false righteousness refers to offerings of mercy (Mt 6:2-4). Giving to the needy was a crucial duty for pious Jews (cf. Dt 15:7-11) ${ }^{22}$. The mercy of God required that people would show mercy to each other, as has already been stated in the fifth beatitude (Mt 5:7). In Matthew, Jesus interprets the holiness code in terms of the mercy code (Snodgrass 1996:111). Everybody would have accepted that it was a religious duty to help the poor, but Jesus points out that it can be done in an objectionable manner. When almsgiving is no longer what it purports to be, that is, service to God, it can no longer be regarded as an act of mercy (Morris 1992:136). To be regarded as a righteous deed, such offering must be done for the benefit of the needy and not to seek public recognition for it. Hands (1968:26) points out that, when the wealthy helped the poor in an honour and shame culture, it was often self-regarding in that the giver anticipated more honour for himself. Almsgiving was an important means in patron-client relationships to maintain social stratification. The wealthy would look down on the poor with ridicule. ${ }^{23}$ A striking example of this is Seneca's wise man who would provide relief but not for pity or sorrow (Clem. 2.6.6). In such a case, almsgiving is misused for the sake of self-esteem. Jesus teaches that it is important to give but not to be known to give. Unrighteous acts of almsgiving are performed by hypocrites. The word 'hypocrite' was mostly used for actors who consciously performed in a play. Batey (1971:563) indicates that Matthew consciously alludes to a 'hypocrite' as actor and speculates whether Jesus' use of the term comes from his contact with the theatre in Sepphoris. Performing acts of righteousness in a hypocritical manner implies that worship is turned into a spectacle. Hypocrites act with ethical pretence. The identity of the disciples does not lie in seeking public admiration but in enacting God's saving mercy. It is assumed that disciples would share resources with the needy. Such acts would denote the presence of God's empire.

19.The Second Temple period in Jewish history is the period between 530 BCE and $70 \mathrm{CE}$.

20.'It is generally believed that the book was written in the second century BCE on the basis of the scrupulous attention to ritual details and the stress laid upon giving alms' (Wikipedia n.d.)

21.Tobit 12:8: 'Prayer is good with fasting and alms and righteousness. A little with righteousness is better than much with unrighteousness. It is better to give alms than to lay up gold: For alms doth deliver from death, and shall purge away all sin.

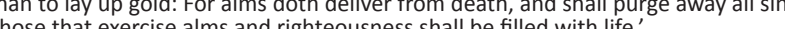

22.Poverty was very common in those days and the lot of the poor very hard.

23.'Poverty ... makes people the target of ridicule, not of assistance' (Juvenal, Sat 3.147-154). 
The second example of true or false righteousness refers to praying (Mt 6:5-15). It seems that, as with almsgiving, there was a tendency amongst those who prayed to use their prayers as a means of impressing others with their piety. Jesus' teaching on praying in a righteous manner consists of two warnings on how not to pray, each balanced by positive teaching ( $\mathrm{Mt} \mathrm{6:5-6;} \mathrm{5:7-8)} \mathrm{followed} \mathrm{by} \mathrm{the}$ model prayer (Mt 6:9-15). The first warning contrasts the disciples' lifestyle with the piety of the Jews in the synagogue (Carter 2000:161). Matthew's Jesus warns against the public pretence of hypocrites when praying. Righteous praying should be done in private and not for show. ${ }^{24}$ Seeking public approval for praying implies that prayer ceases to express love for God but serves the one praying. Instead, prayer is intended as communication with God and not as means to build one's reputation in front of people (Morris 1992:139). The second warning is against verbosity when praying. This warning defines the disciples' prayer over against that of the Gentiles. Jesus compares such praying with the long-winded babbling ${ }^{25}$ of the pagans to get the attention of the gods or even the repetition of magical formulas (Betz 1995:365). The Greek Magical Papyri evidence the use of meaningless sounds believed to be the language of gods (Betz 1992:161-162). Righteous praying is done in simplicity. The model prayer then provides a positive illustration in contrast to the hypocritical performance of the Jews in the synagogue and the babbling of the heathen prayers. This prayer expresses a worldview and shapes the community that prays it (Carter 2000:169). It depicts the heaven, the place where God's will is done, and the earth, the location of the prayers and the place of disobedience. Evil confronts God's order on earth whilst the prayer seeks the manifestation of God's kingdom on earth. Those who pray form a community of children on earth. They know God as their Father and yearn to do his will on earth amidst evil and temptation. They depend on God's grace to sustain their existence. They pray for a transformation of life to be in accordance to God's will.

The third religious activity related to righteousness refers to fasting (Mt 6:16-18). ${ }^{26}$ The same pattern is found as in the previous teaching on giving and praying. The warning once again is against hypocrisy. Turner (2008) aptly remarks:

Jesus was not impressed ... with a theatrically altered appearance. Such behaviour may have been the norm for actors who sought the crowd's applause, but it is singularly inappropriate for disciples who seek the Father's approval. (p. 191)

Fasting is supposed to express the opposite to greed, injustice and the unequal accumulation of means. This deprivation is intended to humble the one who fasts. This is what is expected of disciples of Jesus. However, done in a hypocritical manner as the Pharisees and the teachers of the Law are accused of doing, it is misused for personal gain and reputation.

24.Jesus forbids hypocritical prayers in public, not sincere prayer in public.

25.The word used of babbling ( $\beta \alpha \tau \tau \alpha \lambda o \gamma \varepsilon \dot{\varepsilon} \omega)$ describes an intentionally repetitive speech pattern similar to the involuntary repetitions of a person who stutters (Turner 2008:185)

26.This link between fasting and righteousness probably echoes the warning of Isaiah $58: 3 f f .:$ 'Yet on the day of fasting, you do as you please and exploit your workers ...'
One can therefore conclude that the righteousness of the deeds in Matthew 6:1 does not lie in what is done but in how it is done. The opponents also gave alms, prayed and fasted, but they did it hypocritically in order to gain personal reputation. These deeds are only regarded as righteous if they are done with sincerity, to honour God and to establish his reign in an evil and unequal society.

The two sections, namely Matthew 5:20-48 and 6:1-18, show similarities. Both begin with a general statement about true righteousness (Mt 5:20; 6:1). Both of these statements are followed by a number of practical examples that exhibit repetition, symmetry and contrast amongst them. Higher righteousness is described as honest internal intentions that lead to external actions. Righteousness encompasses both the theoretical and practical aspects of religious conduct that is acceptable to God.

\section{The disciples are to seek the kingdom of heaven and its

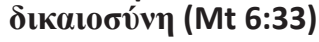

The fifth and last occurrence of righteousness in the Sermon

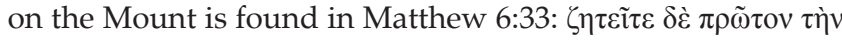

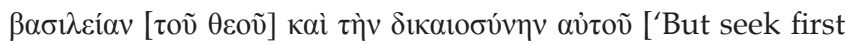
his kingdom and his righteousness, and all these things will be given to you as well'].

From Matthew 5:21 onwards, Jesus explains the righteousness of his disciples that should surpass that of the Pharisees and teachers of the Law. He describes the distinct lifestyle of the community of disciples. Along with the beatitudes (Mt 5:3-12) and the encouragement to be the light of the world and the salt for the earth (Mt 5:13-16), God's rule shapes this way of life. The examples continue in Matthew 6:19-34, with a focus on materialism and daily necessities. Jesus recognises the necessity of material provision but warns against not trusting God for his provision and a desire for material goods whilst depriving others of their means. In the Greco-Roman world, one's wealth or lack of it reflected one's social status (Carter 2000:172). In Matthew 6:33, the disciples are exhorted to seek God's kingdom and his righteousness as their first

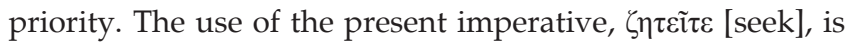
significant (Thom 2009:335). Righteousness should be sought continuously. This would be regarded as the highest value of discipleship. This positive command balances the prohibition of anxiety in Matthew 6:31. A selfish quest for material goods defines the identity and goals of people who seek personal benefit. The community of disciples is defined by a different goal. They want God's kingdom to be established. ${ }^{27}$ Betz (1995:481) fittingly regards this sentence as the telos formula and culmination of the argument on righteousness. Similarly Deines (2004:441) views this sentence as the summary of the message of the Sermon on the Mount.

Matthew is a prolific user of the word Kingdom. ${ }^{28}$ The kingdom has both present and future significance (Morris 1992:161).

27.This implicitly might have been intended as contrast to the Roman empire of that time.

28. $\beta \alpha \sigma i \lambda \varepsilon i ́ \alpha$ [kingdom] occurs 55 times in Matthew, 20 times in Mark and 46 times in Luke. 
It indicates God's rule, now and in the eschatological age. Kingdom should be understood as rule rather than realm (Marcus 1988:663-675; Van der Walt 2006:39). It refers to the fact that God is ruling rather than to an area over which He is sovereign. God's reign has already been established amongst disciples through the ministry of Jesus (Mt 4:17; 12:28). However, it final goal has not yet been reached. The disciples should strive for the completion of God's purposes by praying for it (Mt 6:10), living the distinctive life style as required by God's rule and anticipating the completion of God's purposes.

The righteousness in Matthew 6:33 occurs in the same context as the statements about righteousness in Matthew 5:20 and $6: 1$, which refers to the practice of righteousness. The command in Matthew 6:33 would therefore be that people under God's rule should constantly be seeking to do his will. In line with such an interpretation, Lloyd-Jones (1976:143) remarks: '[Jesus] is not telling his hearers how to make themselves Christian; but He is telling them how to behave because they are Christian.' Seeking righteousness implies 'thoroughgoing and determined obedience to the deepest intent of the law' (Mohrlang 1984:113). These actions seek to establish a society where justice is served and God's rule is manifested. One could interpret the kaì between kingdom and righteousness epexegetically (Hagner 1992:114). This would exemplify the lifestyle of disciples in anticipation of God's final rule and eschatological delivery.

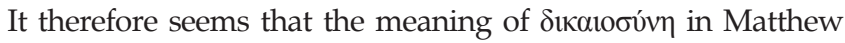
6:33 corresponds with those in Matthew 5:20 and 6:1. Matthew 6:33 makes the implication of righteousness more explicit by linking it to a warning against greed and anxiety for material needs. The norm for the disciples' conduct is based on a specific interpretation of the Torah. By following Jesus and his interpretation of the Torah, people find their identity as citizens of the kingdom of God. They should exercise their identity as citizens of this kingdom by acting righteously according to the precepts given by Jesus. Righteousness implies observing all that Jesus commanded (Mt 28:20).

\section{Conclusion}

Righteousness forms an important theme in the Sermon on the Mount. It starts off in the beatitudes with those who hunger and thirst for righteousness (Mt 5:6) and are persecuted for the sake of righteousness ( $\mathrm{Mt}$ 5:10). The theme continues with the call for greater righteousness (Mt 5:20), which confirms the fundamental statement on the continuing validity of the Law (Mt 5:17-19) and is illustrated by six antithetical examples (Mt 5:21-47). This righteousness is described in terms of being perfect (Mt 5:48). The disciples are called to aim for better righteousness in their attitudes and actions than that of the scribes and the Pharisees. The theme is continued with a general statement about righteousness in Matthew 6:1 to introduce warnings and teachings on religious practices that cannot be regarded as righteous because they are done in a theatrical manner. The pretentious 'piety' of the hypocrites as described in Matthew 6:2-18 is unacceptable within Matthew's community. This theme is concluded with the disciples being called first to seek God's kingdom and his righteousness (Mt 6:33), thus making explicit the meaning of righteousness as doing the will of God.

Righteousness is a goal for Jesus' disciples to pursue. In the

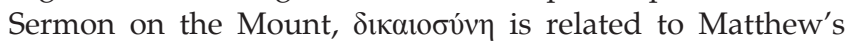
emphasis on 'doing the will of God' (cf. Mt 7:21; 12:46-50). Righteousness gives expression to Matthew's understanding of the practice of true discipleship.

The identity of disciples is thus defined by their distinctive righteousness. As a distinctive group, they act distinctively. Separated from those who oppress and persecute them, they are the blessed ones. They should continuously strive towards righteousness. Their righteousness should outweigh that of the Pharisees and teachers of the Law as they should reveal the true intention of God's will. This righteousness is not captured in legal principles but must exceed what is commonly expected. Their acts of piety should not be pretentious like those of the outsiders and intended for enhancing their social status. Disciples should share the means of living and trust God to provide in their needs. In anticipation of God's final rule, they should strive towards establishing God's rule in their society.

An individual who wants to be part of the Matthean community needs to be loyal to the teaching of Jesus about the Torah and earnestly and continuously yearn towards what is regarded as true righteousness ( $\mathrm{Mt}$ 5:6). Matthew explains in terms of the righteousness of his community why they suffer rejection by those who do not follow Jesus' teaching (Mt 5:10). He distinguishes the identity of his community by comparing their righteousness with that of the scribes and Pharisees (Mt 5:20). He regards the outsider groups' righteousness as superficial and labels it as hypocritical (Mt 6:1). Followers of Jesus are regarded as citizens of the kingdom of God. Matthew encourages his recipients to act as citizens of the kingdom of God by exercising righteousness, as defined by Jesus (Mt 6:33). With the coming of the kingdom, its citizens are called to a new standard of righteousness. For Matthew,

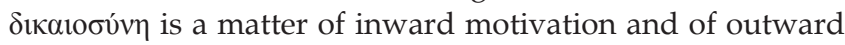
performance directly related to the following of Jesus.

The call to righteousness is based on the existing relationship between Jesus and his disciples. Righteousness is required in this relationship, but not to create it. True discipleship is demonstrated by doing the will of God as defined and interpreted by Jesus. Doing the will of God is what Matthew regards as the distinguishing mark of the disciple community. Thus they would surpass the righteousness of the scribes and Pharisees.

\section{Acknowledgements Competing interests}

The author declares that he has no financial or personal relationship(s) that may have inappropriately influenced him in writing this article. 


\section{References}

Barth, G., 1963, 'Matthew's understanding of the Law', in G. Bornkamm, G. Barth \& H.J. Held (eds.), Tradition and interpretation in Matthew, pp. 59-164, SCM, London.

Batey, R., 1971, 'Jesus and the theatre', New Testament Studies 30, 563-574. http:// dx.doi.org/10.1017/S0028688500013242

Beare, F.W., 1981, The Gospel according to St. Matthew, Blackwell, Oxford.

Betz, H.D., 1992, The Greek magical papyri in translation including the demonic spells, University Press, Chicago.

Betz, H.D., 1995, The Sermon on the Mount including the Sermon on the plain (Matthew 5:3-7:27 and Luke 6:20-49), Fortress Press, Minneapolis. (Hermeneia A critical and historical commentary on the Bible).

Bratcher, R.G., 1989, “'Righteousness” in Matthew', Bible Translator 40, 228-235.

Bultmann, R., 1951, Theology of the New Testament, vol. 1, University Press, Oxford.

Burridge, R.A., 1992, What are the gospels? A comparison with Greco-Roman Biography, University Press, Cambridge. (Society for New Testament Studies Monograph, ser. 70)

Carter, W., 2000, 'Matthew and the margins: A socio-political and religious reading', Journal for the Study of the New Testament, suppl. ser. 204.

Davies, W.D. \& Allison, D.C., 2004, Matthew 1-7, vol. 1, International critical commentary, T \& T Clark, London \& New York.

Deines, R., 2004, Die Gerechtigkeit der Tora im Reich des Messias: Mt 5,13-20 als Schlüsseltext der matthäischen Theologie, Wissenschaftliche Untersuchungen zum Neuen Testament 177, Mohr Siebeck, Tübingen.

Deines, R., 2008, 'Not the law but the Messiah: Law and righteousness in the Gospe of Matthew - An ongoing debate', in D.M. Gurtner \& J. Nolland (eds.), Built upon the Rock: Studies in the Gospel of Matthew, pp. 53-84, William B. Eerdmans, the Rock: Studies in the
Grand Rapids/Cambridge.

Domeris, W.R., 1990, “'Blessed are you ..." (Matthew 5:1-12)', Journal of Theology for Southern Africa 73(1), 67-76.

Floor, L., 1969, De nieuwe exodus: Representatie en inkorporatie in het Nieuwe Testament, PU vir $\mathrm{CHO}$, Potchefstroom.

Foster, P., 2004, Community, law and mission in Matthew's Gospel, Mohr Siebeck, Tübingen. (Wissenschaftliche Untersuchugen zum Neuen Testament, 2, Reihe 177).

France, R.T., 1989, Matthew: Evangelist and teacher, Intervarsity Press, Downers Grove.

Green, H.B., 2001, 'Matthew, poet of the beatitudes', Journal for the Study of the New Testament, suppl. ser. 203.

Guelich, R.A., 1982, The Sermon on the Mount: A foundation for understanding, Word, Waco.

Gundry, R.H., 1982, Matthew: A commentary on his literary and theological art William B. Eerdmans, Grand Rapids.

Hagner, D.A., 1992, 'Righteousness in Matthew's theology', in M.J. Wilkens \& T. Paige (eds.), Worship, theology and ministry in the early church, pp. 101-120, JSOT Press, Sheffield. (Journal for the Study of the New Testament, suppl. ser. 87)

Hands, A.R., 1968, Charities and social aid in Greece and Rome, Cornell University Press, New York.

Hanson, K.C., 1994, 'How honourable! How shameful! A cultural analysis of Matthew's Makarisms and reproaches', Semeia 68, 81-111.

Harrington, D.J., 1991, Gospel of Matthew, Liturgical, Collegeville.

Keener, C.S., 2009, The Gospel of Matthew: A socio-rhetorical commentary, William B. Eerdmans, Grand Rapids/Cambridge.

Kennedy, G.A., 1980, Classical rhetoric and its Christian and secular tradition from ancient to modern times, University of North Carolina, Chapel Hill.

Kilpatrick, G.D., 1946, The origins of the Gospel according to St. Matthew, Clarendon Press, Oxford. PMid:20281617

Koch, K., 1974, Was ist Formgeschichte? Neue Wege der Bibelexegese, Neukirchener Verlag, Neukirchener Verlag.

Lioy, D., 2004, The Decalogue in the Sermon on the Mount, Peter Lang, New York. (Studies in Biblical Literature, 66).

Lloyd-Jones, D.M., 1976, Studies in the Sermon on the Mount, William B. Eerdmans, Grand Rapids.
Loader, W.R.G., 1997, Jesus' attitude towards the Law: A study of the Gospels, Mohr Siebeck, Tübingen. (Wissenschaftliche Untersuchungen zum Neuen Testament 2. Reihe).

Luz, U., 1990, Matthew 1-7: A commentary, T \& T Clark, Edinburgh.

Mack, B.L., 1990, Rhetoric and the New Testament: Guides to biblical scholarship Fortress Press, Minneapolis.

Marcus, J., 1988, 'Entering into the kingly power of God', Journal of Biblical Literature 107, 663-675. http://dx.doi.org/10.2307/3267628

Mohrlang, R., 1984, Matthew and Paul: A comparison of ethical perspectives, University Press, Cambridge. (Society for New Testament Studies Monograph, ser. 48).

Morris, L., 1992, The Gospel according to Matthew, William B. Eerdmans, Grand Rapids.

Neisser, U., 1967, Cognitive psychology, Meredith, New York.

Neusner, J. \& Frerichs, E.S. (eds.), 1985, 'To see ourselves as others see us': Christians, Jews, 'others' in late antiquity, Scholars Press, Chicago.

Plummer, A., 1915, An exegetical commentary on the Gospel according to St. Matthew, Robert Scott, London.

Przybylski, B., 1980, Righteousness in Matthew and his world of thought, Cambridge University Press, Cambridge. (Monograph Series).

Qimron, E. \& Strugnell, J., 1994, Qumran cave 4: Discoveries in the Judaean desert, Clarendon, Oxford.

Roitto, R., 2011, Behaving as a Christ-Believer: A cognitive perspective on identity and behaviour norms in Ephesians, Eisenbrauns, Winona Lakes.

Saldarini, A.J., 1994, Matthew's Christian-Jewish community, University of Chicago, Chicago/ London. PMid:7887011

Sanders, E.P., Baumgarten, A.I, Mendelsohn, A. \& Meyer, B.F. (eds.), 1982, Jewish and Christian self definition, 3 vols., Fortress, Philadelphia.

Sim, D.C., 1999, The Gospel of Matthew and Christian Judaism: The history and social setting of the Matthean community, T\&T Clark, Edinburg.

Snodgrass, K., 1996, 'Matthew and the law', in D.R. Bauer \& M.A. Powell (eds.) Treasures new and old: Contributions to Matthean studies, pp. 99-127, Scholars Press, Atlanta.

Stott, J. R.W., 1978, The message of the Sermon on the Mount (Matthew 5-7): Christian counter culture, Inter-Varsity Press, Downers Grove.

Strack, H. \& Billerbeck, P., 1961, Kommentar zum Neuen Testament aus Talmud und Midrash, Beck, Munick.

Strecker, G., 1971, Der Weg der Gerechtigkeit: Untersuchung zur de Matthäus, Vandenhoeck \& Ruprecht, Göttingen.

Tagawa, K., 1970, 'People and community in the Gospel of Matthew', New Testament Studies 16, 149-162. http://dx.doi.org/10.1017/S0028688500015460

Talbert, C.H., 1992, 'Biography ancient', in D.N. Freedman (ed.), Anchor Bible dictionary, vol. 1, pp. 745-749, Doubleday, New York.

Talbert, C.H., 2010, Matthew, Paideia commentaries on the New Testament, Baker Academic, Grand Rapids.

Theissen, G., 2007, Erleben und Verhalten der Ersten Christen: Eine Psychologie des Urchristentums, Gütersloh Verlags-Haus, Gütersloh.

Thom, J.C. 2009, 'Justice in the Sermon on the Mount', Novum Testamentum 51 314-338. http://dx.doi.org/10.1163/156853609X432792

Turner, D.L., 2008, Matthew, Baker, Grand Rapids. (Baker exegetical commentary on the New Testament).

Van Aarde, A., 1994, 'God-with-us: The dominant perspective in Matthew's story', HTS Teologiese Studies/Theological Studies, suppl. 5

Van der Walt, T., 2006, Die Messias het gekom, Potchefstroomse Teologiese Publikasies, Potchefstroom

Viljoen, F.P., 2011, 'The foundational statement in Matthew 5:17-20 on the continuing validity of the Law', In die Skriflig 45(2/3), 385-408. http://dx.doi.org/10.4102/ ids.v45i2\&3.20

Viljoen, F.P., 2012, 'Interpreting the visio Dei in Matthew 5:8', HTS Teologiese Studies/ Theological Studies 68(1), Art. \#905, 7 pages. http://dx.doi.org/10.4102/hts. v68i1.905

Wikipedia, n.d., Book of Tobit, viewed n.d., from http://en.wikipedia.org/wiki/Book of_Tobit

Wilkins, M.J., 1988, The concept of disciple in Matthew's gospel as reflected in the use of the term $\mu \alpha \theta$ ntńs, Brill, Leiden. 